\title{
Homology-Dependent Virus Resistance in Transgenic Plants with the Coat Protein Gene of Sweet Potato Feathery Mottle Potyvirus: Target Specificity and Transgene Methylation
}

\author{
S. Sonoda, M. Mori, and M. Nishiguchi
}

National Institute of Agrobiological Resources, Kan-nondai 2-1-2, Tsukuba, Ibaraki 305-8602, Japan. Accepted for publication 28 January 1999.

\begin{abstract}
Sonoda, S., Mori, M., and Nishiguchi, M. 1999. Homology-dependent virus resistance in transgenic plants with the coat protein gene of sweet potato feathery mottle potyvirus: Target specificity and transgene methylation. Phytopathology 89:385-391.

Nicotiana benthamiana plants were transformed with the coat protein (CP) coding sequence and the $3^{\prime}$ nontranslated region (NTR) of the severe strain of sweet potato feathery mottle potyvirus (SPFMV-S). Regenerated lines were screened for virus resistance using recombinant potato virus $\mathrm{X}$ (PVX) engineered to contain the sequence homologous to the transgene.

the recombinant PVX. In most of the resistant lines, relatively low steadystate accumulation of the $\mathrm{CP}$ gene mRNA and little or no protein products were observed, suggesting that the resistance was manifested by a posttranscriptional gene-silencing mechanism. The resistant lines could be divided into two groups according to the target specificity of the silencing mechanism; one group recognizing the $3^{\prime}$ part of the transgene mRNA and the other not only the $3^{\prime}$ part, but also the $5^{\prime}$ and the central part of the transgene mRNA. Particular regions of the transgene corresponding to the RNA target in the resistant lines were differentially methylated compared with the transgene sequence in a susceptible line.
\end{abstract} Out of 19 transgenic lines, 7 showed virus resistance after inoculation by
Transgenic plants expressing virus genes or sequences have been shown to be resistant to plant virus infections (3). This form of resistance is known as pathogen-derived resistance (PDR) (21). PDR is manifested at either the protein or the RNA level. In proteinmediated resistance, usually there is a direct correlation between the level of protein accumulation in plants and the virus resistance. On the other hand, RNA-mediated resistance is typically associated with transgenic plants with low or undetectable transgene expression. This type of resistance is referred to as homology-dependent virus resistance (HDR) (2).

HDR, which operates via a mechanism similar to that of cosuppression or posttranscriptional gene silencing, depends on sequence homology between the transgene and the target gene $(5,8,12,17)$. It has been suggested that HDR could operate in the cytoplasm and eliminate both viral RNA and the transgene transcript $(6,12)$. Plants displaying this virus-resistant phenotype transcribe the transgene at a high rate yet accumulate the transgene transcript at low levels $(5,23,25)$. The high nuclear transcription rates of the transgene can be partly attributed to the presence of multiple copies in the genomes of the resistant plants (9). Exceeding a RNA threshold level may be required to activate the cytoplasmic posttranscriptional RNA degradation process and elicit virus resistance $(12,23)$. No significant correlation between the nuclear transcription rates of transgenes and the establishment of HDR was found by Mueller et al. (17) or English et al. (8). In these cases, DNA methylation of the transgene may have been associated with HDR (8).

We have determined the complete nucleotide sequence of the severe strain of sweet potato feathery mottle potyvirus (SPFMV-S) $(16,19)$. In the current study, we report HDR of Nicotiana benthamiana transformed with the coat protein (CP) coding sequence and the $3^{\prime}$ nontranslated region (NTR) of SPFMV-S against potato

Corresponding author: S. Sonoda; E-mail address: ssono@abr.affrc.go.jp

Publication no. P-1999-0312-01R

(C) 1999 The American Phytopathological Society virus $\mathrm{X}$ (PVX), engineered to contain the sequence homologous to the transgene. Furthermore, we report the target specificity of the resistance mechanism and the transgene methylation.

\section{MATERIALS AND METHODS}

Construction of plant expression vectors. The origin of SPFMV-S has been reported (26). SPFMV-S does not infect $N$. benthamiana (26).

Routine DNA and RNA manipulations were performed according to Sambrook et al. (20). The $5^{\prime}$ terminal region of the CP gene of the SPFMV-S genome (nucleotides 9,652 to 10,079) was amplified by polymerase chain reaction (PCR) from a cDNA clone, pVC2, that contains the $3^{\prime}$-half of the NIa gene, the NIb gene, the CP gene, and the $3^{\prime}$ NTR of SPFMV-S (16), using the $5^{\prime}$ - and $3^{\prime}$-end primers, 5'-GGCCGGATCCAACAATGTCTAGTGAACGTACTGAATTCAAAGATGCGGGA-3' (italic letters are nucleotides 9,652 to 9,684) and 5'-CCCTCATACCATGCTTGAAACTGTTCTTGAG-3' (nucleotides 10,049 to 10,079), respectively (Fig. 1). The $5^{\prime}$-end primer was designed to contain a BamHI restriction site (underlined letters) and the CP translational start codon (bold letters). PCR conditions were 25 cycles of $45 \mathrm{~s}$ at $94^{\circ} \mathrm{C}, 45 \mathrm{~s}$ at $60^{\circ} \mathrm{C}$, and $1 \mathrm{~min}$ at $72^{\circ} \mathrm{C}$. The PCR-amplified fragment of the $\mathrm{CP}$ gene was digested with BamHI and SalI and cloned into similarly digested pBluescript II SK+ (pMM1; Stratagene, La Jolla, CA) (Fig. 1). The SalI-NotI fragment of pVC2, corresponding to nucleotides 10,045 to 10,820 of the SPFMV-S RNA sequence, was cloned into the SalI-NotI sites of pBluescript II SK+ (pMM2) (Fig. 1). The BamHI-SalI and SalI-SacI fragments of pMM1 and pMM2, respectively, were inserted between the $35 \mathrm{~S}$ cauliflower mosaic virus promoter and the nopaline synthase terminator sequences of the binary plasmid, pBI121 (Clontech Labs, Palo Alto, CA) after the GUS gene had been removed. The resulting plasmid was denoted as pMM4 and used for plant transformation (Fig. 1).

PCR-based, site-directed mutagenesis was used to introduce a modification into the nucleotide sequence for the amino acid triplet, 
Asp-Ala-Gly (DAG), which has been shown to be essential for the aphid transmission (1). The $5^{\prime}$ terminal region of the $\mathrm{CP}$ gene of the SPFMV-S genome (nucleotides 9,662 to 10,209) was amplified by PCR from $\mathrm{pVC} 2$ using the $5^{\prime}$ - and $3^{\prime}$-end primers, 5'GTACTGAATTCAAAGATAAGGGAG-3' (nucleotides 9,662 to 9,685) and 5'-CTCATCACCATCCATCATAGTCC-3' (nucleotides 10,187 to 10,209), respectively (Fig. 1). The $5^{\prime}$-end primer was designed to modify the DAG motif to Ala-Asn-Gly (DKG) and to contain an EcoRI restriction site (underlined letters). The PCRamplified fragment of the CP gene was digested with EcoRI and SalI and cloned into similarly digested pBluescript II SK+ (pMM3) (Fig. 1). The BamHI-SacI fragment of pMM4 was cloned into a modified pBI221 (Clontech Labs), in which the EcoRI restriction site was eliminated by EcoRI digestion followed by a fill-in reaction using the Klenow fragment of DNA polymerase I (pMM5) (Fig. 1). The elimination of the EcoRI site in pBI221 was necessary to remove the EcoRI-SalI fragment from pMM5 without deleting the SalI-SacI fragment (Fig. 1). The EcoRI-SalI fragment of pMM3 was cloned into the EcoRI-SalI site of pMM5 after the EcoRI-SalI fragment had been removed (pMM6) (Fig. 1). The BamHI-SacI fragment of pMM6 was inserted between the $35 \mathrm{~S}$ cauliflower mosaic virus promoter and the nopaline synthase terminator sequences of pBI121. The resulting plasmid was denoted as pMM7 and used for plant transformation (Fig. 1).

Plant transformation and selection. After pMM4 and pMM7 were transferred into Agrobacterium tumefaciens LBA4404 (Clontech Labs), leaf disks of $N$. benthamiana were transformed (10). Calli were obtained and shoots of $N$. benthamiana were produced on the Murashige-Skoog (MS)-based medium supplemented with benzyladenine $(0.1 \mu \mathrm{g} / \mathrm{ml}), \alpha$-naphthalene acetic acid $(0.1 \mu \mathrm{g} / \mathrm{ml})$, kanamycin $(100 \mu \mathrm{g} / \mathrm{ml})$, and claforan $(100 \mu \mathrm{g} / \mathrm{ml})$. The shoots were subsequently rooted on hormone-free medium containing kanamy-

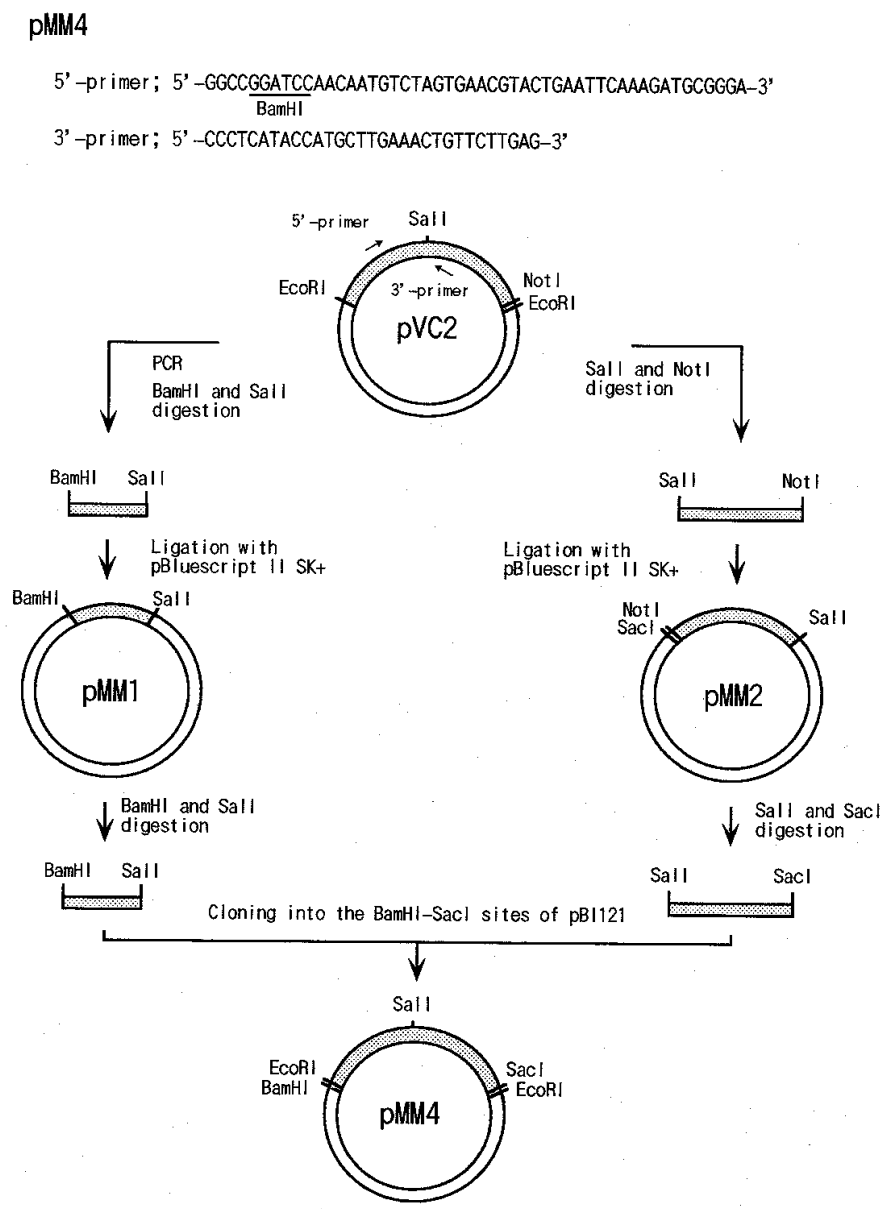

cin $(100 \mu \mathrm{g} / \mathrm{ml})$ in a growth chamber at $25^{\circ} \mathrm{C}$ under a $16 / 8$-h (light/ dark) photoperiod. Rooted plants were transferred to soil and grown in the greenhouse.

Analysis of transgene expression. $T_{1}$ seedling progeny from selffertilized $\mathrm{T}_{0}$ transgenic plants were analyzed for the expression of the transgene. Total RNA was isolated from leaf tissue as described in Verwoerd et al. (27). Total RNA $(15 \mu \mathrm{g})$ was size-fractionated on a $1.2 \%$ agarose gel containing $0.66 \mathrm{M}$ formaldehyde and transferred to Hybond-N+ (Amersham International, Little Chalfont, United Kingdom). The blot was hybridized with a random-primed ${ }^{32} \mathrm{P}$-labeled fragment containing the CP coding sequence (20).

Southern blot analysis. Genomic DNA was isolated from the leaf tissue as described by Murray and Thompson (18) and digested with restriction enzymes. Total DNA $(20 \mu \mathrm{g})$ digested with restriction enzymes was size-fractionated on a 1.2 or $1.5 \%$ agarose gel, transferred to Hybond-N+ (24), and hybridized with a ${ }^{32} \mathrm{P}-$ labeled CP gene-specific probe (20).

PVX constructs and virus infection. The PVX constructs used in this study are illustrated in Figure 2. The PVX vector $\mathrm{pP} 2 \mathrm{C} 2 \mathrm{~S}$, a derivative of pGC3 (4) that can be used to express foreign genes in plants, was kindly provided by D. C. Baulcombe (The Sainsbury Laboratory, Norwich, United Kingdom). The plasmid pVC2 described above was digested with EcoRI, or EcoT22I (an isoschizomer of NsiI) and EcoRI, or SalI and EcoT22I. The resulting CP gene fragments were end-filled using the Klenow fragment of DNA polymerase I, gel-purified, and ligated into the EcoRV site of pP2C2S to produce PVX.CPI, PVX.CPII, and PVX.CPV, respectively. PVX.CPIV was derived from PVX.CPII by deleting the DNA fragment between the SalI sites. For the production of PVX.CPIII, pVC2 was digested with SalI. The resulting CP fragment was ligated into the SalI cloning site of pP2C2S. PVX.CPIII was digested with EcoT22I and SalI, and the resulting DNA frag-

pMM7

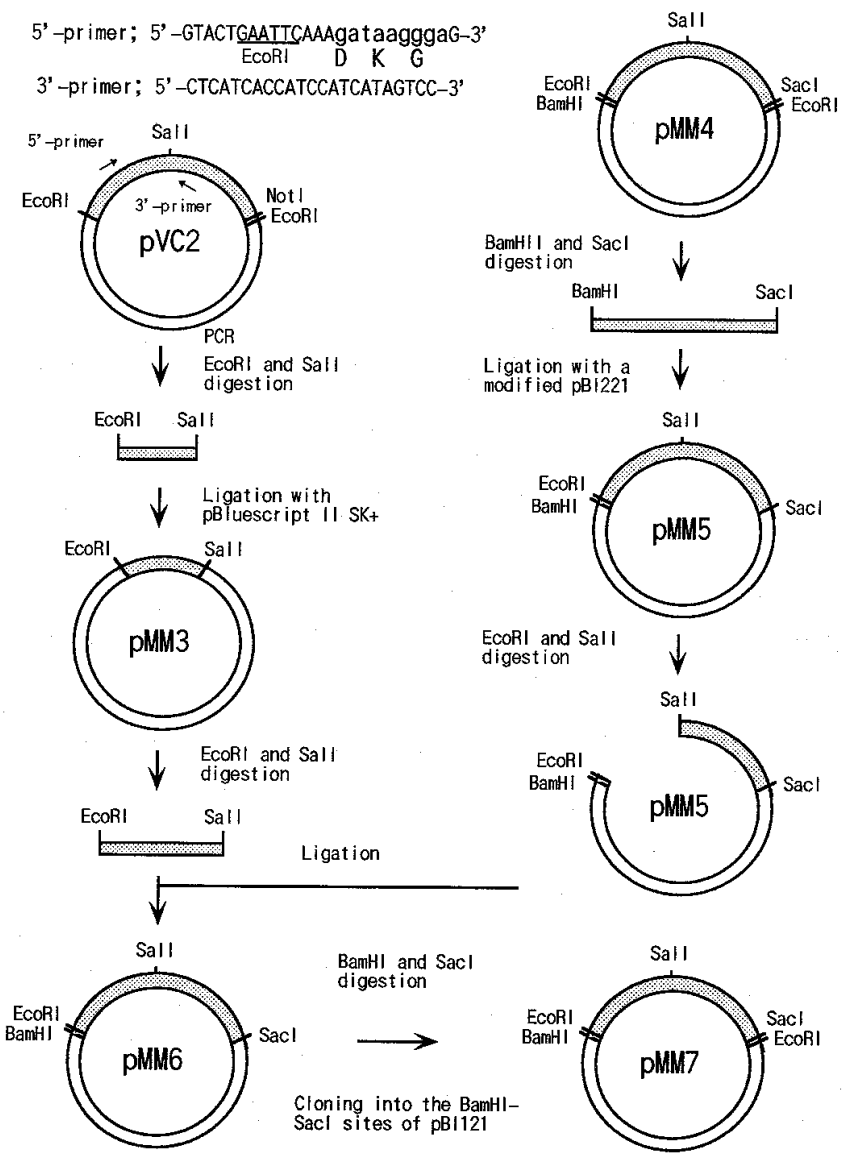

Fig. 1. Construction of the plasmids pMM4 and pMM7 used for plant transformation. 
ment was end-filled, gel-purified, and ligated into the EcoRV site of $\mathrm{pP} 2 \mathrm{C} 2 \mathrm{~S}$ to produce PVX.CPVI.

All PVX constructs used in this study were linearized with SpeI, extracted with phenol/chloroform, and ethanol-precipitated before use in transcription reactions. Transcription reactions contained $40 \mathrm{mM}$ Tris-HCl, $\mathrm{pH} 8.0 ; 25 \mathrm{mM} \mathrm{NaCl} ; 8 \mathrm{mM} \mathrm{MgCl} 2 ; 2 \mathrm{mM}$ spermidine; $10 \mathrm{mM}$ dithiothreitol; $2 \mathrm{mM}$ each of ATP, UTP, and CTP; $0.2 \mathrm{mM}$ GTP; $0.25 \mathrm{mM}$ cap analogue $\mathrm{m}^{7} \mathrm{G}\left(5^{\prime}\right) \mathrm{ppp}\left(5^{\prime}\right) \mathrm{G}$; $0.7 \mathrm{U}$ of RNase inhibitor per ml (Toyobo, Osaka, Japan); $0.1 \mu \mathrm{g}$ of linearized DNA per $\mu \mathrm{l}$; and $5 \mathrm{U}$ of T7 RNA polymerase per $\mu \mathrm{l}$ (Gibco BRL, Rockville, MD). After $25 \mathrm{~min}$ at $37^{\circ} \mathrm{C}$, GTP was added to bring the final concentration to $2 \mathrm{mM}$, and the reactions were further incubated for $35 \mathrm{~min}$ at $37^{\circ} \mathrm{C}$.

Seedlings (about 4 to 5 weeks old) of $\mathrm{T}_{2}$ transgenic plant lines and control plants were used to evaluate resistance to viral infection. Virus-infected leaf homogenates were used for virus inoculation. The leaf homogenates were prepared by grinding systemically infected leaf tissue diluted (1:10) in $10 \mathrm{mM}$ phosphate buffer ( $\mathrm{pH}$ 7.0). Inoculated plants were monitored daily for the appearance of symptoms.

\section{RESULTS}

Transformation of the CP gene and the $3^{\prime}$ NTR of SPFMV-S in transgenic plants. Ten transgenic lines transformed with pMM4 and nine lines transformed with pMM7 were regenerated in the presence of kanamycin. All of the transgenic lines appeared normal in morphology and development. Each line was selfed, and the resulting $\mathrm{T}_{1}$ progeny were used for further analysis.

$\mathrm{T}_{1}$ transgenic lines transformed with pMM4 or pMM7 were analyzed by northern blot hybridization for expression of the transgene. Two distinct transcripts were observed in all plants in which the expression could be detected by northern blot analysis (Fig. 3). The smaller transcript of 1.3 kilobases $(\mathrm{kb})$ was consistent with the size expected for the CP gene, the $3^{\prime} \mathrm{NTR}$, and their bordering vector sequences. The other transcript was not characterized further. Different levels of transcript accumulation were observed among transgenic lines. Southern blot hybridization of BamHI-, EcoRV-, HindIII-, PstI-, or XbaI-digested plant DNA with the SPFMV-S $\mathrm{CP}$-specific sequence showed that one to three copies of the transgene were present in transgenic lines. (Southern blots are not shown, but the results are indicated in Fig. 3.) There was an apparent correlation between transgene copy number and the low steadystate accumulation of the transgene transcript (Fig. 3).

Response of transgenic plants to virus inoculation. We introduced nearly the entire CP coding sequence and the $3^{\prime}$ NTR of SPFMV-S into the genome of PVX (4) to produce PVX.CPI (Fig. 2).

Inoculation of lines 4.03, 4.09, 7.11, 7.12, and 7.22 with PVX.CPI always resulted in a high proportion of plants that were completely
PVX Constructs

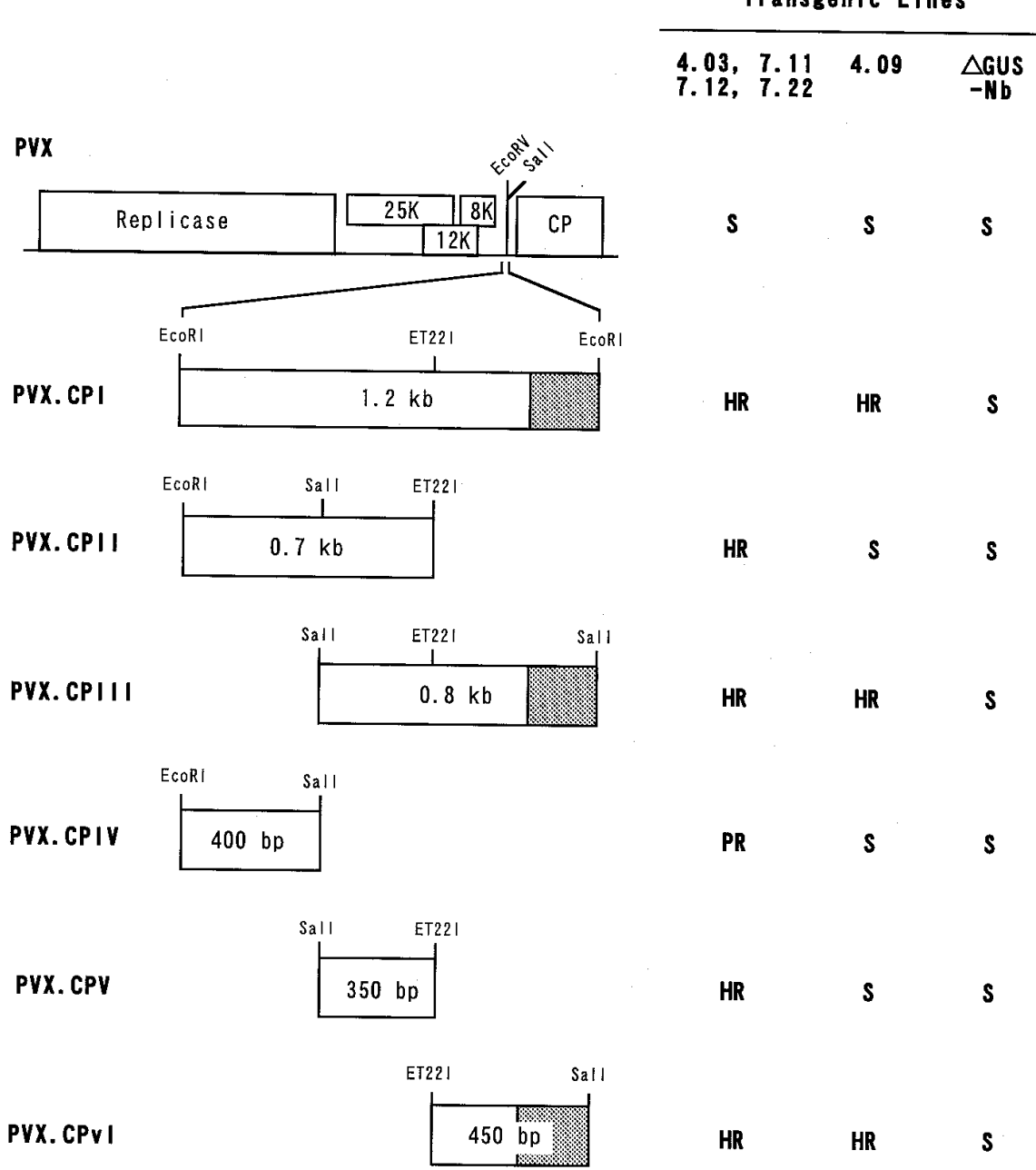

Fig. 2. Constructs of recombinant potato virus X (PVX) and response of transgenic lines. The severe strain of sweet potato feathery mottle potyvirus (SPFMV-S) sequences corresponding to smaller parts of the coat protein gene and the $3^{\prime}$ nontranslated region (NTR) were inserted into the PVX genome. The 3' NTR of SPFMV-S is represented by shaded boxes. The sequences were inserted in the sense orientation. The vector-transformed Nicotiana benthamiana plants ( $\Delta$ GUS$\mathrm{Nb})$ and five resistant lines $(4.03,4.09,7.11,7.12$, and 7.22) were inoculated with sap from recombinant PVX-infected plants. Reactions of the transgenic plants could be grouped into three phenotypes: $\mathrm{HR}=$ highly resistant, all or a high proportion of plants remained free of symptoms; PR = partially resistant, all plants were systemically infected after a 1- to 9-day delay relative to control plants; and S = sensitive, all plants developed the same severe mosaic symptoms as control plants. nt $=$ Not tested . 
resistant to PVX.CPI infection (Fig. 2, Table 1). However, a small number of plants displayed symptoms typical of those induced by PVX when inoculated with PVX.CPI. Most of the plants were susceptible in lines 4.28 and 4.35 when inoculated with PVX.CPI (Table 1). However, the number of virus-resistant plants was increased when a lower inoculum concentration (1:100 dilution) was employed (Table 1), suggesting dose-dependent resistance. The remaining 12 transgenic lines were susceptible to PVX.CPI (data not shown). All resistant lines displayed symptoms when inoculated with PVX (Fig. 2, Table 1). Lines 4.03, 4.09, 7.11, 7.12, and 7.22 , in which a high proportion of plants showed resistance to PVX.CPI infection, were chosen to investigate the target specificity within the CP coding sequence and the $3^{\prime}$ NTR.

Target specificity within the CP gene and the $3^{\prime}$ NTR. To determine the target specificity of lines 4.03, 4.09, 7.11, 7.12, and 7.22 within the CP sequence and the $3^{\prime}$ NTR, we analyzed the effect of deletions within the transgene sequence in the PVX vector without affecting infectivity. A schematic representation of the PVX constructs that were used for virus inoculation is shown in Figure 2.

All plants in lines 4.03, 7.11, 7.12, and 7.22 were completely resistant to PVX.CPII carrying the $5^{\prime}$ terminal 700 base pairs (bp) of the transgene (Fig. 2, Table 1). No resistance to PVX.CPII was observed in line 4.09 (Table 1). All five resistant lines displayed resistance against PVX.CPIII, which contained sequence corresponding to the $3^{\prime}$ terminal $800 \mathrm{bp}$ of the transgene (Fig. 2, Table 1). All five lines were completely susceptible to inoculation of PVX.CPIV containing sequence corresponding to the $5^{\prime}$ terminal $400 \mathrm{bp}$ of the transgene (Fig. 2, Table 1). However, partial resistance (a delay in symptom appearance) was observed in lines 4.03, $7.11,7.12$, and 7.22, whereas no such resistance was observed in line 4.09 (Fig. 2). Lines 4.03, 7.11, 7.12, and 7.22 were highly resistant to PVX.CPV carrying the central $350 \mathrm{bp}$ of the transgene (Fig. 2, Table 1). No resistance to PVX.CPV was observed in line 4.09 (Fig. 2, Table 1). All five resistant lines displayed resistance to PVX.CPVI carrying the $3^{\prime}$ terminal $450 \mathrm{bp}$ of the transgene (Fig. 2, Table 1). These results suggest that the target specificity within the transgene for degradation is different among individual lines. The degradation mechanism in line 4.09 might occur through recognition of the $3^{\prime}$ part of the transgene mRNA. In contrast, the degradation in lines $4.03,7.11,7.12$, and 7.22 seems to occur through recognition of not only the $3^{\prime}$ part, but also the $5^{\prime}$ and the central part of the transgene mRNA.

Methylation at the transcribed region of the transgene. The correlation between virus resistance and methylation of the transgene was examined by Southern blot analysis using the cytosine methylation-sensitive restriction endonucleases HpaII, HaeIII, and Sau3AI in combination with $X b a \mathrm{I}$ and the $\mathrm{CP}$-specific probe. The absence of methylation in the $X b a \mathrm{I}$ site of the transgene in the lines used was confirmed by Southern blot analysis (data not shown). Recognition sequences for HpaII, HaeIII, and Sau3AI are distributed throughout the transgene sequences (Fig. 4).

HpaII-XbaI digestion of DNA extracted from the resistant lines $4.03,7.11,7.12$, and 7.22 produced a 1.8 -kb fragment (Fig. 4B), indicating that HpaII sites 1 and 2 were fully methylated. Each of these four lines produced specific higher-molecular-weight fragments in addition to a common 1.8-kb fragment, indicating that HpaII site 3 was partially methylated in these lines. The resistant line 4.09 produced $0.4-$ and $1.7-\mathrm{kb}$ fragments, but did not produce 0.9- and 1.4-kb fragments, indicating that HpaII sites 2 and 3 were fully methylated and that HpaII site 1 was not (Fig. 4A and B). The susceptible line 7.05 produced $1.3-\mathrm{kb}$ and specific highermolecular-weight fragments larger than $1.8 \mathrm{~kb}$ (Fig. 4B). This indicated that HpaII sites 1 and 3 were fully methylated and that HpaII site 2 was partially methylated (Fig. 4A).

HaeIII-XbaI digestion of DNA extracted from the resistant lines $4.03,7.11$, and 7.22 produced fragments of $0.35,0.85,1.2$, and $1.5 \mathrm{~kb}$ (Fig. 4B), indicating that HaeIII sites 1 and 2 were partially methylated and that HaeIII site 3 was not (Fig. 4A). In the resis-

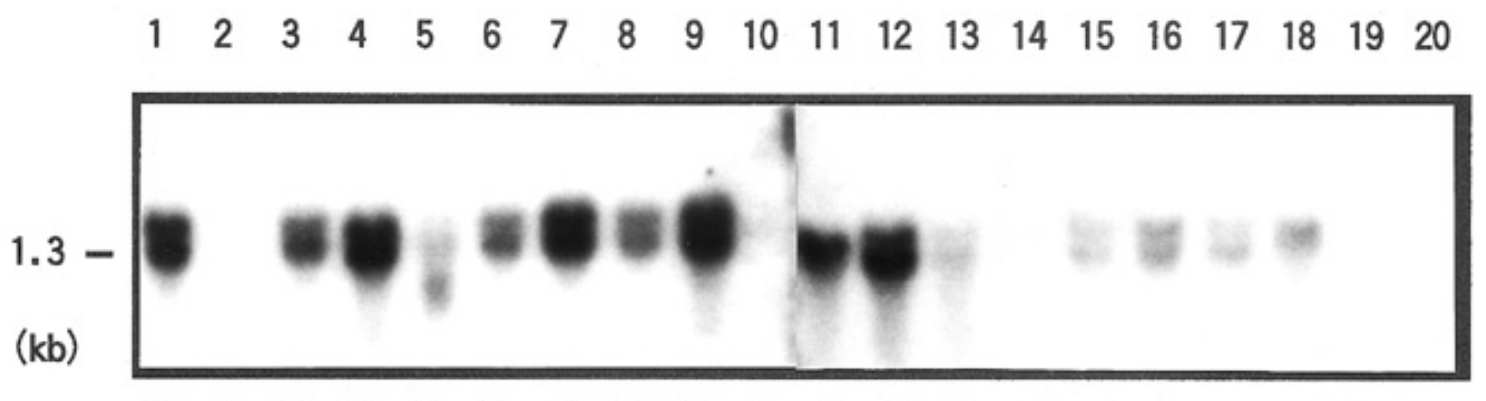

(1) (2) (1) (1) (1) (1) (1) (1) (2) (2) (2) (1) (3) (2) (1) (2) (1) (1) (2) (0)

Fig. 3. Northern blot analysis of RNA from transgenic Nicotiana benthamiana plants. Total RNA (15 $\mu \mathrm{g})$ from various transgenic lines was subjected to denaturing gel electrophoresis, transferred to a nylon membrane, and hybridized with a ${ }^{32} \mathrm{P}$-labeled coat protein gene-specific probe. RNA samples were examined from the following plant lines: lane 1, 4.02; lane 2, 4.03; lane 3, 4.05; lane 4, 4.07; lane 5, 4.09; lane 6, 4.10; lane 7, 4.11; lane 8, 4.13; lane 9, 4.28; lane 10, 4.35; lane 11, 7.05; lane 12, 7.09; lane 13, 7.11; lane 14, 7.12; lane 15, 7.14; lane 16, 7.16; lane 17, 7.17; lane 18, 7.21; 1ane 19, 7.22; and lane 20, the control line transformed with GUS-deleted pBI121 ( $\triangle$ GUS-Nb). Numbers in parentheses indicate the copy number of the transgene estimated by Southern blot analysis.

TABLE 1. Infectivity of recombinant potato virus $\mathrm{X}(\mathrm{PVX})$ in transgenic Nicotiana benthamiana lines

\begin{tabular}{|c|c|c|c|c|c|c|c|c|}
\hline \multirow[b]{2}{*}{ Line } & \multicolumn{8}{|c|}{ Inoculum $^{\mathrm{a}}$} \\
\hline & PVX & PVX.CPI & PVX.CPII & PVX.CPIII & PVX.CPIV & PVX.CPV & PVX.CPVI & 1:100 PVX.CPI \\
\hline 4.03 & $10 / 10^{\mathrm{b}}$ & $5 / 10$ & $0 / 10$ & $0 / 6$ & $10 / 10$ & $0 / 6$ & $1 / 10$ & $\mathrm{nt}$ \\
\hline 4.35 & $10 / 10$ & $5 / 6$ & nt & $\mathrm{nt}$ & $\mathrm{nt}$ & nt & $\mathrm{nt}$ & $3 / 18$ \\
\hline 7.11 & $10 / 10$ & $2 / 10$ & $0 / 10$ & $0 / 4$ & $10 / 10$ & $0 / 5$ & $0 / 5$ & nt \\
\hline 7.12 & $10 / 10$ & $3 / 10$ & $0 / 10$ & $1 / 6$ & $10 / 10$ & $1 / 6$ & $1 / 10$ & $\mathrm{nt}$ \\
\hline
\end{tabular}

a Plant sap (diluted 10-fold) from $N$. benthamiana plants infected with recombinant PVX was applied at the three- and four-leaf stage.

${ }^{b}$ The values represent the number of infected plants over the total number tested for virus resistance. $\mathrm{nt}=$ Not tested. 


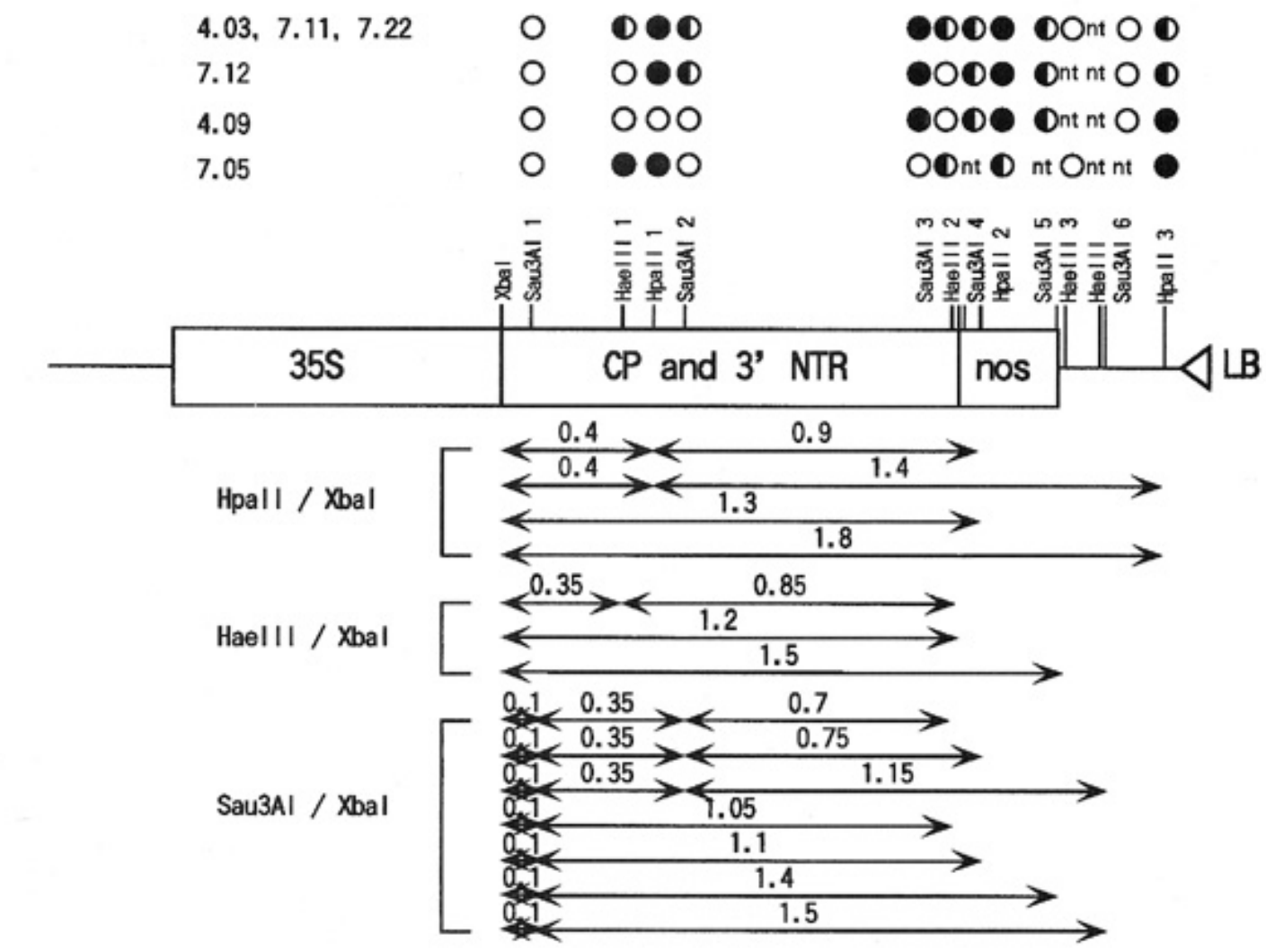

B

HpalI/Xbal

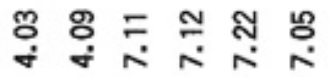

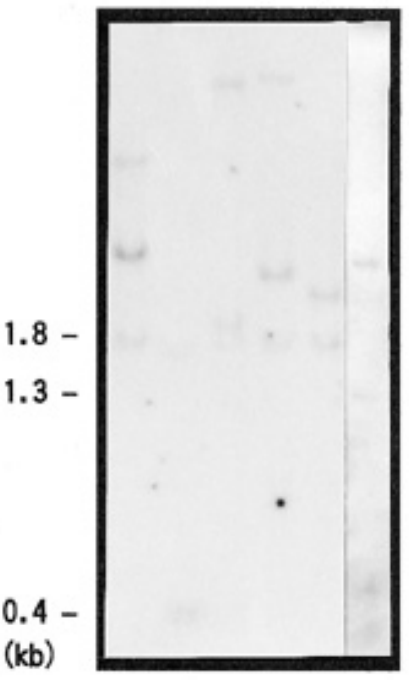

HaellII/Xbal
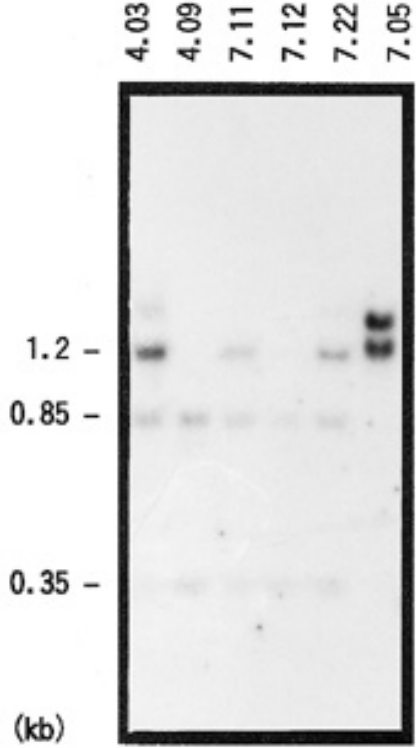

Sau3AI/Xbal

\%

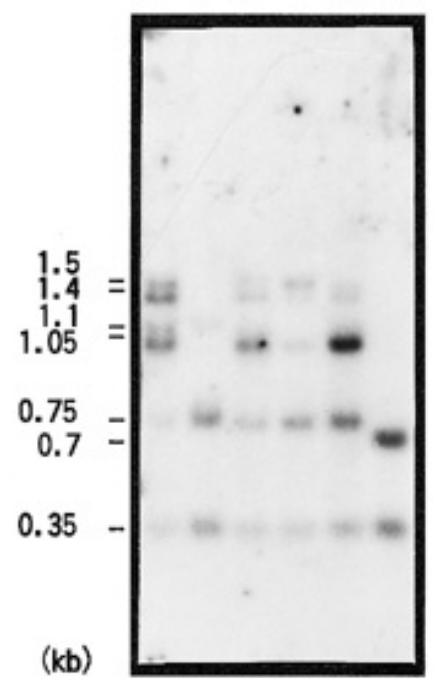

Fig. 4. Methylation status of the transgenes in the five resistant lines $(4.03,4.09,7.11,7.12$, and 7.22) and the susceptible line (7.05). A, Restriction map of the transgene present in the resistant and the susceptible lines is shown for HpaII, HaeIII, and Sau3AI. Restriction site for XbaI is also shown. The methylation status for each restriction site based on Southern blots is indicated as follows: open circle = unmethylated; partially filled circle = partially methylated; filled circle = fully methylated; and $\mathrm{nt}=$ not tested. $\mathrm{LB}=\mathrm{T}$-DNA left border; nos $=$ nopaline synthase $3^{\prime}$ end; $\mathrm{CP}$ and $3^{\prime}$ NTR $=$ the coat protein coding sequence and the $3^{\prime}$ nontranslated region of the severe strain of sweet potato feathery mottle potyvirus, respectively; and $35 \mathrm{~S}=$ cauliflower mosaic virus $35 \mathrm{~S}$ promoter. $\mathbf{B}$, Southern blots of the resistant and susceptible lines using the methylation-sensitive restriction enzymes HpaII, HaeIII, and Sau3AI in combination with XbaI. Total DNA $(20 \mu \mathrm{g})$ digested with restriction enzymes was size-fractionated on an agarose gel, transferred to a nylon membrane, and hybridized with a ${ }^{32} \mathrm{P}$ labeled CP gene-specific probe. The numbers indicate the size of DNA fragments in kilobases $(\mathrm{kb})$. 
tant lines 7.12 and $4.09,0.35$ - and $0.85-\mathrm{kb}$ fragments were observed, indicating that HaeIII sites 1 and 2 were not methylated (Fig. 4A and B). The susceptible line 7.05 produced fragments of 1.2 and $1.5 \mathrm{~kb}$ (Fig. 4B). This indicated that HaeIII sites 1 and 2 were fully and partially methylated, respectively, and that HaeIII site 3 was not (Fig. 4A and B).

Sau3AI-XbaI digestion of DNA extracted from the resistant lines $4.03,7.11,7.12$, and 7.22 produced fragments of $0.35,0.75,1.05$, 1.1, 1.4, and $1.5 \mathrm{~kb}$ (Fig. 4B). This suggested that Sau3AI site 3 and sites 2, 4, and 5 were fully and partially methylated, respectively, and that Sau3AI sites 1 and 6 were not (Fig. 4A). The resistant line 4.09 produced 0.35-, 0.75-, and a small amount of $1.15-\mathrm{kb}$ fragments, suggesting that Sau3AI site 3 and sites 4 and 5 were fully and partially methylated, respectively, and that Sau3AI sites 1, 2, and 6 were not (Fig. 4A and B). The susceptible line 7.05 produced fragments of 0.35 and $0.7 \mathrm{~kb}$ (Fig. 4B). This suggested that Sau3AI sites 1 to 3 were not methylated (Fig. 4A). A fragment of $0.1 \mathrm{~kb}$, which is produced by digestion of the $\mathrm{Xba \textrm {I }}$ site and Sau3AI site 1, was not detected in the blot (Fig. 4B); therefore, we cannot rule out the possibility that Sau3AI site 1 in the resistant and susceptible lines was methylated. However, fragments of $0.45,1.15$, and $1.2 \mathrm{~kb}$, which are supposed to be produced by methylation of Sau3AI site 1, were not detected in any of the lines (Fig. 4B). Thus, we considered it plausible that Sau3AI site 1 was not methylated.

\section{DISCUSSION}

We have shown a complete resistance of transgenic $N$. benthamiana plants, expressing either an intact or a mutated version of the SPFMV-S CP gene and the 3' NTR, to the unrelated virus PVX engineered to contain sequence homologous to the transgene sequences. In most of the resistant plant lines (lines 4.03, 4.09, 4.35, $7.11,7.12$, and 7.22), relatively low steady-state accumulation of the transgene mRNA was observed (Fig. 3). Furthermore, little or no protein product was observed in western blots (data not shown). These results suggest that the resistance is mediated by a posttranscriptional gene-silencing mechanism that suppresses in trans the accumulation of RNA of homologous transgenes and confers HDR $(5,8,12,17)$.

We have also shown that the target specificity was different among the resistant lines (Fig. 2, Table 1). The silencing mechanism in line 4.09 was found to be targeted toward the $3^{\prime}$ part of the transgene mRNA. Targeting of the $3^{\prime}$ region of the transgene mRNA has been observed in several transgenic tobacco plants in which the transgene sequences were silenced $(8,11,22)$. On the other hand, the $5^{\prime}$ and the central regions as well as the $3^{\prime}$ region of the transgene mRNA were recognized in lines 4.03, 7.11, 7.12, and 7.22. Recognition of regions in the transgene mRNA other than the $3^{\prime}$ end was also reported in tobacco plants transformed with the replicase gene of tobacco mosaic virus (13).

Posttranscriptional gene silencing of transgene mRNA has been reported to be associated with the state of methylation of transcribed transgene sequences $(14,15,23)$. English et al. (8) reported that the $3^{\prime}$ region of the silenced GUS transgene, in which DNA methylation was concentrated, was the specific target of the gene silencing. In the current study, DNA methylation was distributed throughout the transgene sequence in lines 4.03, 7.11, 7.12, and 7.22 , in which the silencing mechanism recognizes not only the $3^{\prime}$ part but also the $5^{\prime}$ and the central parts of the transgene mRNA (Fig. 4). The transgene sequence of line 4.09, in which the silencing mechanism recognizes the $3^{\prime}$ part of the transgene mRNA, was highly methylated in the $3^{\prime}$ part. There seems to be a significant correlation between DNA methylation within the transgenes and the RNA target specificity in these lines. However, unexpectedly, the transgene in the susceptible line 7.05 was also highly methylated and the state of methylation was similar to that in lines 4.03, 7.11, 7.12, and 7.22. These resistant (4.03, 7.11, 7.12, and
7.22) and susceptible (7.05) lines contained multiple copies of the transgene (Fig. 3); therefore, the state of methylation might be merely a consequence of DNA-DNA interactions of transgene sequences and might not be involved in the posttranscriptional genesilencing phenomena observed. However, we do not rule out the possibility that posttranscriptional gene silencing is related to transgene methylation. English and Baulcombe (7) showed that posttranscriptional gene silencing may be very sensitive to small changes in the transgene. The small differences in methylation status observed between the resistant and susceptible lines such as that in Sau3AI site 3 and HpaII site 2 might play a critical role in the gene silencing. Alternatively, the methylation status in areas other than in the restriction sites analyzed in this study might be significant. Modification of the state of DNA methylation in both resistant and susceptible lines might affect the silencing phenotype and reveal more information about gene silencing and DNA methylation in transgenic plants.

\section{ACKNOWLEDGMENTS}

This research was supported, in part, by the Grant-in-Aid "Integrated Research Program for the Use of Biotechnological Procedures for Plant Breeding" from the Ministry of Agriculture, Forestry and Fisheries of Japan. We thank D. C. Baulcombe (The Sainsbury Laboratory, Norwich, United Kingdom) for providing the PVX vector; M. Zaitlin (Cornell University, Ithaca, NY) for English correction; and the Japan Science and Technology Corporation (JST) for the award of a Domestic Research Fellowship to S. Sonoda.

\section{LITERATURE CITED}

1. Atreya, C. D., Raccah, B., and Pirone, T. P. 1990. A point mutation in the coat protein abolishes aphid transmissibility of a potyvirus. Virology 178:161-165.

2. Baulcombe, D. C. 1996. Mechanisms of pathogen-derived resistance to viruses in transgenic plants. Plant Cell 8:1833-1844.

3. Beachy, R. N. 1997. Mechanisms and applications of pathogen-derived resistance in transgenic plants. Curr. Opin. Biotechnol. 8:215-220.

4. Chapman, S. N., Kavanagh, T. A., and Baulcombe, D. C. 1992. Potato virus $\mathrm{X}$ as a vector for gene expression in plants. Plant J. 2:549-557.

5. Dougherty, W. G., Lindbo, J. A., Smith, H. A., Parks, T. D., Swaney, S., and Proebsting, W. 1994. RNA-mediated virus resistance in transgenic plants: Exploitation of a cellular pathway possibly involved in RNA degradation. Mol. Plant-Microbe Interact. 7:544-552.

6. Dougherty, W. G., and Parks, T. D. 1995. Transgene and gene suppression: Telling us something new? Curr. Opin. Cell. Biol. 7:399-405.

7. English, J. J., and Baulcombe, D. C. 1997. The influence of small changes in transgene transcription on homology-dependent virus resistance and gene silencing. Plant J. 12:1311-1318.

8. English, J. J., Mueller, E., and Baulcombe, D. C. 1996. Suppression of virus accumulation in transgenic plants exhibiting silencing of nuclear genes. Plant Cell 8:179-188.

9. Goodwin, J., Chapman, K., Swaney, S., Parks, T. D., Wernsman, E. A., and Dougherty, W. G. 1996. Genetic and biochemical dissection of transgenic RNA-mediated virus resistance. Plant Cell 8:95-105.

10. Horsch, R. B., Fry, J. E., Hoffman, N. L., Eicholtz, D., Rogers, S., and Fraley, R. T. 1985. A simple and general method for transferring genes into plants. Science 227:1229-1231.

11. Lee, K. Y., Baden, C., Howie, W. J., Bedbrook, J., and Dunsmuir, P. 1997. Post-transcriptional gene silencing of ACC synthase in tomato results from cytoplasmic RNA degradation. Plant J. 12:1127-1137.

12. Lindbo, J. A., Silva-Rosales, L., Proebsting, W. M., and Dougherty, W. G. 1993. Induction of a highly specific antiviral state in transgenic plants: Implications for regulation of gene expression and virus resistance. Plant Cell 5:1749-1759.

13. Marano, M. R., and Baulcombe, D. C 1998. Pathogen-derived resistance targeted against the negative strand RNA of tobacco mosaic virus: RNA strand-specific gene silencing? Plant J. 13:537-546.

14. Matzke, M. A., Priming, M., Tronovsky, J., and Matzke, A. J. M. 1989. Reversible methylation and inactivation of marker genes in sequentially transformed tobacco plants. EMBO (Eur. Mol. Biol. Organ.) J. 8:643-649.

15. Meyer, P., Heidmann, I., and Neidenhof, I. 1993. Differences in DNAmethylation are associated with a paramutation phenomenon in transgenic petunia. Plant J. 4:89-100.

16. Mori, M., Sakai, J., Kimura, T., Usugi, T., Hayashi, T., Hanada, K., and 
Nishiguchi, M. 1995. Nucleotide sequence analysis of two nuclear inclusion body and coat protein genes of a sweet potato feathery mottle virus severe strain (SPFMV-S) genomic RNA. Arch. Virol. 140:1473-1482.

17. Mueller, E., Gilbert, J., Davenport, G., Brigneti, G., and Baulcombe, D. C. 1995. Homology-dependent resistance: Transgenic virus resistance in plants related to homology-dependent gene silencing. Plant J. 7:1001-1013.

18. Murray, M. G., and Thompson, W. F. 1980. Rapid isolation of high molecular weight plant DNA. Nucleic Acids Res. 8:4321-4325.

19. Sakai, J., Mori, M., Morishita, T., Tanaka, M., Hanada, K., Usugi, T., and Nishiguchi, M. 1997. Complete nucleotide sequence and genome organization of sweet potato feathery mottle virus ( $\mathrm{S}$ strain) genomic RNA: The large coding region of the P1 gene. Arch. Virol. 142:1553-1562.

20. Sambrook, J., Fritsch, E. F., and Maniatis, T. 1989. Molecular Cloning, 2nd ed. Cold Spring Harbor Laboratory, Cold Spring Harbor, NY.

21. Sanford, J. C., and Johnson, S. A. 1985. The concept of parasite-derived resistance: Deriving resistance genes from the parasites own genome. J. Theor. Biol. 115:395-405.

22. Sijen, T., Wellink, J., Hiriart, J.-B., and van Kammen, A. 1996. RNA- mediated virus resistance: Role of repeated transgenes and delineation of targeted regions. Plant Cell 8:2277-2294.

23. Smith, H. A., Swaney, S. L., Parks, T. D., Wernsman, E. A., and Dougherty, W. G. 1994. Transgenic plant virus resistance mediated by untranslatable sense RNAs: Expression, regulation, and fate of nonessential RNAs. Plant Cell 6:1441-1453.

24. Southern, E. M. 1975. Detection of specific sequences among DNA fragments separated by gel electrophoresis. J. Mol. Biol. 98:503-517.

25. Swaney, S., Powers, H., Goodwin, J., Silva Rosales, L., and Dougherty, W. G. 1995. RNA-mediated resistance with nonstructural genes from the tobacco etch virus genome. Mol. Plant-Microbe Interact. 8:1004-1011.

26. Usugi, T., Nakano, M., Onuki, M., Maoka, T., and Hayashi, T. 1994. A new strain of sweet potato feathery mottle virus that causes russet crack on fleshy roots of some Japanese cultivars of sweet potato. Ann. Phytopathol. Soc. Jpn. 60:545-554.

27. Verwoerd, T. C., Dekker, B. M. M., and Hoekema, A. 1989. A small scale procedure for the rapid isolation of plant RNAs. Nucleic Acids Res. 17:2362.

\section{Erratum}

\section{Vol. 89, No. 5, 1999}

In the manuscript entitled "Homology-Dependent Virus Resistance in Transgenic Plants with the Coat Protein Gene of Sweet Potato Feathery Mottle Potyvirus: Target Specificity and Transgene Methylation" by S. Sonoda, M. Mori, and M. Nishiguchi (Phytopathology 89:385-391), there are two text changes and one figure labeling change. The second sentence of the second paragraph in Materials and Methods should read 'The 5' terminal region of the CP gene of the SPFMV-S genome (nucleotides 9,652 to 10,079 ) was amplified by polymerase chain reaction (PCR) from a cDNA clone, pVC1, that contains the 3'-half on the NIb gene, the CP gene, and the 3' NTR of SPFMV-S..." The sixth sentence of the second paragraph in Materials and Methods should read "The SalI-NotI fragment of pVC1, corresponding to nucleotides...." Within Figure 1, the two circles labeled "pVC2" should be labeled "pVC1." 